\title{
SYNTHESIS AND ANTITUBERCULAR ACTIVITY OF PIPERIDINE AND MORPHOLINE 1, 8 NAPHTHYRIDINE ANALOGUES
}

\author{
MUWAFFAG BADAWNEH, JALAL ALJAMAL* \\ Faculty of Pharmacy, Jerash University, Jerash, Jordan \\ Email: jaljamal@jpu.edu.jo \\ Received: 16 Jun 2016 Revised and Accepted: 21 0ct 2016
}

\begin{abstract}
Objective: The search for new, potentially useful antimycobacterial agents. In continuation with our previous screening for the discovery of novel drugs for tuberculosis, a new series of 1,8-naphthyridines derivatives were synthesized and evaluated in vitro for antimycobacterial activity against Mycobacterium tuberculosis H37Rv.

Methods: Several 4-morpholinomethyl-1.8-naphthyridine derivatives have been synthesized in excellent yields. The synthesized compounds were characterized by spectroscopic methods as well as elemental analyses. They were screened for their antimycobacterial activity. The growth was monitored radiometrically in 7H12 broth with the BACTEC 460 TB system. The minimum inhibitory concentration (MIC) was determined for compounds that demonstrated $\geq 90 \%$ growth inhibition in the primary screening.
\end{abstract}

Results: The obtained data suggested that all compounds showed significant activity against Mycobacterium tuberculosis H37Rv compared to the standard reference drug. Analogues (6-11) having heterocyclic groups in position 7 were the most potent of those we tested.

Conclusion: These findings clearly identify the 1,8-naphthyridine analogue (10) with a 6-amino-2-(4'-methoxy benzylamine-4-morpholinomethyl7-morpholino-substituent as promising anti-tubercular agents possessing significant activity against Mycobacterium tuberculosis $\mathrm{H} 37 \mathrm{Rv}$

Keywords: Anti-mycobacterial activity, 1,8-naphthyridine, Piperidine, Morpholine

(C) 2016 The Authors. Published by Innovare Academic Sciences Pvt Ltd. This is an open access article under the CC BY license (http://creativecommons.org/licenses/by/4. 0/) DOI: http://dx.doi.org/10.22159/ijpps.2016v8i12.13503

\section{INTRODUCTION}

Tuberculosis (TB) is a major global health problem. It causes illhealth among millions of people each year and ranks alongside the human immunodeficiency virus (HIV) as a leading cause of death worldwide. In 2014, there were an estimated 9.6 million new TB. There were also 1.5 million TB deaths (1.1 million among HIVnegative people and 0.4 million among HIV-positive people) [1]. Mycobacterium tuberculosis, the causative organism, produces a chronic infection in the lungs that can become disseminated. It still remains one of the foremost among infectious disease in the world causing the maximum number of deaths due to the spread of single microorganism [2-5].

The difficulty in managing tuberculosis is the prolonged treatment duration, the emergence of drug resistance and co-infection with HIV/AIDS. The increase in the incidence of drug-resistant TB in HIVinfected individuals is a leading cause of death and is further worsening the TB situation worldwide. The association of tuberculosis with HIV infection is so dramatic that in some cases, nearly two third of the patients diagnosed with the tuberculosis are also HIV seropositive [611]. The disease tuberculosis, once considered eradicated, has again become a major global health concern. The resurgence in the disease is caused by an inadequate and extended chemotherapy that relies on drugs developed in the mid-twentieth century.

Tuberculosis control requires new drugs that act at novel drug targets to help combat resistant forms of M. tuberculosis and reduce treatment duration [12-14].

We have previously $[15,16]$ described the preparation of some 1,8naphthyridine derivatives, bearing various substituents in position 2, 4 and 7 and reported on the results of their in vitro evaluation against M. tuberculosis H37Rv, some of these compounds showed a marked activity.

Taking into account some observations of the structure-activity relationship, a new series of 1,8-naphthyridines derivatives carrying a morpholino methyl group in the 4 position and different groups in the 2 ,
6 and 7 positions of the 1,8-naphthyridine nucleus were synthesized and radiometric analyses were conducted to determine their antitubercular activities against Mycobacterium tuberculosis $\mathrm{H} 37 \mathrm{Rv}$ with the aim to get better antimycobacterial activity.

\section{MATERIALS AND METHODS}

Instrumental analyses

Chemicals used in this study were of analytical grade and obtained from Merck or Sigma.

${ }^{1} \mathrm{H}$ NMR, and ${ }^{13} \mathrm{C}$ NMR spectra were recorded on a Varian CFT-20 NMR spectrometer, in DMSO- $\mathrm{d}_{6}$ or $\mathrm{CDCl}_{3}$ operating at $300 \mathrm{MHz}\left({ }^{1} \mathrm{H}\right.$ NMR), and $75 \mathrm{MHz}\left({ }^{13} \mathrm{C} \mathrm{NMR}\right)$.

Analytical TLC was carried out on E. Merch $0.20 \mathrm{~mm}$ precoated silicagel glass plate (60 F254) and the location of spots was detected by illumination with an UV lamp. Melting points were determined on a kofler hot-stage apparatus and are uncorrected table 1.

Elemental analysis for $\mathrm{C}, \mathrm{H}, \mathrm{N}$ and $\mathrm{Cl}$ was carried out by a micro method using the elemental Vario EL III Elemental analyzer. The results of elemental analysis were within $\pm 0.4 \%$ of the theoretical values, table 1 .

\section{Synthesis}

Preparation of 7-amino-2-(4'-methoxybenzylamine)-4-moroholinomethyl-1,8-naphthyridine (1)

To a mixture of 7-acetylamino-2-chloro-4-morpholinomethyl-1,8naphthyridine derivative (X) (2.0 g, 7.82 mmole $)$ and 4methoxybenzylamine ( $3.55 \mathrm{ml}, 27 \mathrm{mmole}$ ) was added pyridine (35 $\mathrm{ml}$ ) under $\mathrm{N}_{2}$. The mixture was heated to reflux for $48 \mathrm{~h}$ and then cooled to room temperature, the pyridine was removed and the compound (1) was obtained by column chromatography followed by recrystallization table 1 and 2 .

${ }^{13} \mathrm{C}-\mathrm{NMR}\left(\mathrm{CDCl}_{3}\right) \delta$ compound (1), 55.45, 158.62, 114.25, 130.51 $132.20,130.54,114.80,46.41,159.21,112.78,148.51,64.30,55.21$ $66.70,66.70,55.21,107.70,136.3,109.91,158.9,155.60$. 
Table 1: Physical data of 1,8 naphthyridine derivatives

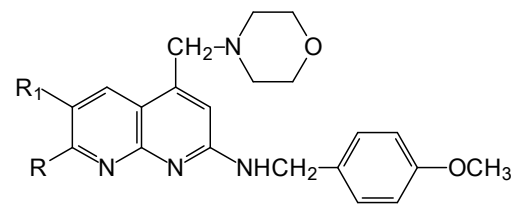

\begin{tabular}{|c|c|c|c|c|c|c|c|c|c|}
\hline \multirow[t]{2}{*}{ Comp. } & \multirow[t]{2}{*}{$\mathbf{R}$} & \multirow[t]{2}{*}{$\mathbf{R}_{\mathbf{1}}$} & \multirow[t]{2}{*}{ Yield \% } & \multirow[t]{2}{*}{ M. P. [a] } & \multirow[t]{2}{*}{ Mol. formula } & \multicolumn{4}{|c|}{ Analysis (calcd/found \%) } \\
\hline & & & & & & C & H & $\mathbf{N}$ & $\mathbf{C l}$ \\
\hline \multirow[t]{2}{*}{1} & \multirow[t]{2}{*}{$\mathrm{NH}_{2}$} & \multirow[t]{2}{*}{$\mathrm{H}$} & \multirow[t]{2}{*}{78} & \multirow[t]{2}{*}{$188-190[\mathrm{~b}]$} & \multirow[t]{2}{*}{$\mathrm{C}_{21} \mathrm{H}_{25} \mathrm{~N}_{5} \mathrm{O}_{2}$} & 66.47 & 6.64 & 18.46 & - \\
\hline & & & & & & 66.42 & 6.66 & 18.41 & - \\
\hline \multirow[t]{2}{*}{2} & \multirow[t]{2}{*}{$\mathrm{OH}$} & \multirow[t]{2}{*}{$\mathrm{H}$} & \multirow[t]{2}{*}{35} & \multirow[t]{2}{*}{$173-175[c]$} & \multirow[t]{2}{*}{$\mathrm{C}_{21} \mathrm{H}_{24} \mathrm{~N}_{4} \mathrm{O}_{3}$} & 66.30 & 6.36 & 14.73 & - \\
\hline & & & & & & 66.27 & 6.34 & 14.72 & - \\
\hline \multirow[t]{2}{*}{3} & \multirow[t]{2}{*}{$\mathrm{OH}$} & \multirow[t]{2}{*}{$\mathrm{NO}_{2}$} & \multirow[t]{2}{*}{28} & \multirow[t]{2}{*}{$143-145[c]$} & \multirow[t]{2}{*}{$\mathrm{C}_{21} \mathrm{H}_{23} \mathrm{~N}_{5} \mathrm{O}_{5}$} & 59.29 & 5.45 & 16.46 & - \\
\hline & & & & & & 59.25 & 5.48 & 16.44 & - \\
\hline \multirow[t]{2}{*}{4} & \multirow[t]{2}{*}{$\mathrm{Cl}$} & \multirow[t]{2}{*}{$\mathrm{H}$} & \multirow[t]{2}{*}{91} & \multirow[t]{2}{*}{$171-173[\mathrm{~b}]$} & \multirow[t]{2}{*}{$\mathrm{C}_{21} \mathrm{H}_{23} \mathrm{~N}_{4} \mathrm{Cl} \mathrm{O}_{2}$} & 63.23 & 5.81 & 14.05 & 8.89 \\
\hline & & & & & & 63.19 & 5.78 & 14.08 & 8.92 \\
\hline \multirow[t]{2}{*}{5} & $\mathrm{Cl}$ & $\mathrm{NO}_{2}$ & 82 & $148-150[\mathrm{~b}]$ & $\mathrm{C}_{21} \mathrm{H}_{22} \mathrm{~N}_{5} \mathrm{Cl} \mathrm{O}_{4}$ & 56.82 & 5.00 & 15.78 & 7.99 \\
\hline & & & & & & 56.79 & 4.97 & 15.81 & 8.02 \\
\hline 6 & Morph & $\mathrm{H}$ & 86 & $154-156[\mathrm{~b}]$ & $\mathrm{C}_{25} \mathrm{H}_{31} \mathrm{~N}_{5} \mathrm{O}_{3}$ & 66.79 & 6.95 & 15.58 & - \\
\hline & & & & & & 66.83 & 6.98 & 15.63 & - \\
\hline 7 & Morph & $\mathrm{NO}_{2}$ & 67 & $152-154[\mathrm{~b}]$ & $\mathrm{C}_{25} \mathrm{H}_{30} \mathrm{~N}_{6} \mathrm{O}_{5}$ & 60.72 & 6.11 & 16.99 & - \\
\hline & & & & & & 60.74 & 6.12 & 17.02 & - \\
\hline 8 & Pip & $\mathrm{H}$ & 71 & $138-140[\mathrm{~d}]$ & $\mathrm{C}_{27} \mathrm{H}_{34} \mathrm{~N}_{4} \mathrm{O}_{2}$ & 72.62 & 7.67 & 12.55 & - \\
\hline & & & & & & 72.65 & 7.70 & 12.55 & - \\
\hline 9 & Pip & $\mathrm{NO}_{2}$ & 66 & $137-139$ [d] & $\mathrm{C}_{27} \mathrm{H}_{33} \mathrm{~N}_{5} \mathrm{O}_{4}$ & 65.97 & 6.77 & 14.25 & - \\
\hline & & & & & & 66.00 & 6.78 & 14.27 & - \\
\hline 10 & Morph & $\mathrm{NH}_{2}$ & 80 & $148-150[\mathrm{~d}]$ & $\mathrm{C}_{25} \mathrm{H}_{32} \mathrm{~N}_{6} \mathrm{O}_{3}$ & 64.63 & 6.94 & 18.09 & - \\
\hline & & & & & & 64.60 & 6.91 & 18.11 & - \\
\hline 11 & Pip & $\mathrm{NH}_{2}$ & 74 & $138-140[\mathrm{~b}]$ & $\mathrm{C}_{27} \mathrm{H}_{35} \mathrm{~N}_{5} \mathrm{O}_{2}$ & 70.25 & 7.64 & 15.17 & - \\
\hline & & & & & & 70.21 & 7.65 & 15.20 & - \\
\hline
\end{tabular}

[a] recrystallization solvent [b] toluene [c] separated by flash chromatography with EtOAc as solvent [d] petroleum ether $100-140^{\circ} \mathrm{C}$

Table 2: ${ }^{1} \mathrm{H}-\mathrm{NMR}$ Chemical shifts ( $\delta$ PPM/TMS)

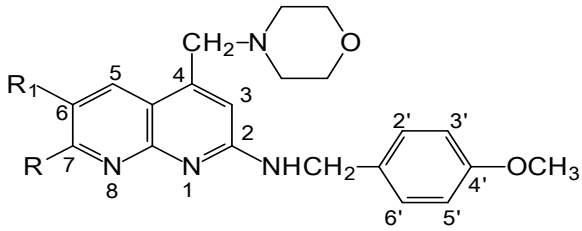

\begin{tabular}{|c|c|c|c|c|c|c|c|c|c|c|c|c|c|}
\hline \multirow[t]{2}{*}{ Comp. } & \multirow{2}{*}{$\begin{array}{l}\mathbf{H}_{3} \\
\text { (s) }\end{array}$} & \multirow[t]{2}{*}{$\mathbf{H}_{5}$} & \multirow{2}{*}{$\begin{array}{l}\mathbf{H}_{6} \\
\text { (d) }\end{array}$} & \multirow{2}{*}{$\begin{array}{l}\mathrm{C}_{6} \mathrm{H}_{5} \\
(\mathrm{~m})\end{array}$} & \multirow{2}{*}{$\begin{array}{l}\text { NH- } \\
(\mathrm{t})\end{array}$} & \multirow{2}{*}{$\begin{array}{l}-\mathrm{CH}_{2-}- \\
(\mathrm{t}) \\
-\mathrm{CH}_{2-} \\
\text { (s) }\end{array}$} & \multirow{2}{*}{$\begin{array}{l}4^{\prime}- \\
\mathrm{OCH}_{3} \\
\text { (s) }\end{array}$} & \multirow{2}{*}{$\begin{array}{l}\text { Morph } \\
\text { (m) }\end{array}$} & \multirow[t]{2}{*}{ Pip (m) } & \multicolumn{4}{|c|}{ Others (d) } \\
\hline & & & & & & & & & & $\mathbf{H}_{2}$ & $\mathbf{H}_{3^{\prime}}$ & $\mathbf{H}_{5}$ & $\mathbf{H}_{6}$ \\
\hline 1 & 7.47 & $\begin{array}{l}6.47 \\
\text { (d) }\end{array}$ & 7.15 & 7.31 & 7.18 & $\begin{array}{l}3.10 \\
3.15\end{array}$ & 3.72 & $3.13,3.51$ & & 7.84 & 7.74 & 7.17 & 6.92 \\
\hline 2 & 7.88 & $\begin{array}{l}6.58 \\
\text { (d) }\end{array}$ & 7.48 & 7.25 & 7.25 & $\begin{array}{l}3.22 \\
3.35\end{array}$ & 3.58 & $3.41,3.63$ & & 7.85 & 7.83 & 7.25 & 6.75 \\
\hline 3 & 7.98 & $\begin{array}{l}8.35 \\
(\mathrm{~s})\end{array}$ & - & 7.68 & 7.32 & $\begin{array}{l}3.21 \\
3.21\end{array}$ & 3.54 & $3.38,3.49$ & & 7.93 & 7.96 & 7.18 & 6.87 \\
\hline 4 & 8.15 & $\begin{array}{l}6.32 \\
\text { (d) }\end{array}$ & 7.59 & 7.62 & 7.33 & $\begin{array}{l}3.35 \\
3.25\end{array}$ & 3.47 & $3.21,3.61$ & & 7.77 & 7.84 & 7.29 & 6.91 \\
\hline 5 & 7.74 & $\begin{array}{l}8.21 \\
\text { (s) }\end{array}$ & - & 7.78 & 7.55 & $\begin{array}{l}3.45 \\
3.22\end{array}$ & 3.52 & $3.28,3.65$ & & 7.71 & 7.92 & 7.31 & 7.11 \\
\hline 6 & 7.68 & $\begin{array}{l}6.28 \\
\text { (d) }\end{array}$ & 7.11 & 7.84 & 7.41 & $\begin{array}{l}3.41 \\
3.32\end{array}$ & 3.55 & $\begin{array}{l}3.30,3.55 \\
3.48,3.91\end{array}$ & & 7.93 & 7.74 & 7.14 & 6.65 \\
\hline 7 & 6.81 & $\begin{array}{l}8.19 \\
(\mathrm{~s})\end{array}$ & - & 7.59 & 7.35 & $\begin{array}{l}3.49 \\
3.41\end{array}$ & 3.63 & $\begin{array}{l}3.24,3.48 \\
3.51,3.88\end{array}$ & & 7.91 & 7.62 & 7.28 & 6.84 \\
\hline 8 & 7.68 & $\begin{array}{l}6.18 \\
\text { (d) }\end{array}$ & 7.68 & 7.68 & 7.51 & $\begin{array}{l}3.55 \\
3.41\end{array}$ & 3.69 & $3.29,3.64$ & $1.53,3.40$ & 7.97 & 7.48 & 7.41 & 6.94 \\
\hline 9 & 7.92 & $\begin{array}{l}8.31 \\
(\mathrm{~s})\end{array}$ & - & 7.74 & 7.58 & $\begin{array}{l}3.41 \\
3.32\end{array}$ & 3.72 & $3.41,3.73$ & $1.48,3.55$ & 7.84 & 7.67 & 7.46 & 6.84 \\
\hline 10 & 7.55 & $\begin{array}{l}8.32 \\
(\mathrm{~s})\end{array}$ & - & 7.81 & 7.65 & $\begin{array}{l}3.47 \\
3.34\end{array}$ & 3.76 & $\begin{array}{l}3.50,3.81 \\
3.31,3.74\end{array}$ & & 7.66 & 7.81 & 7.17 & 6.81 \\
\hline 11 & 7.25 & $\begin{array}{l}8.47 \\
(\mathrm{~s})\end{array}$ & - & 7.48 & 7.48 & $\begin{array}{l}3.33 \\
3.28 \\
\end{array}$ & 3.66 & $3.34,3.60$ & $1.59,3.64$ & 7.78 & 7.82 & 7.28 & 6.96 \\
\hline
\end{tabular}


Preparation of 7-hydroxy-2-(4'-methoxybenzylamine)-4morpholinomethyl-1,8-naphthyridine (2) and 7-hydroxy-6nitro-2-(4'-methoxybenzylamine)-4-morpholinomethyl-1,8naphthyridine (3)

To a solution of 1.0 mmole of 7-amino derivative (1) in $5 \mathrm{ml}$ of concentrated sulfuric acid, sodium nitrite was added portion wise at $-5^{\circ} \mathrm{C}$, after standing at room temperature for $1 \mathrm{~h}$ crushed ice was added and then concentrated ammonium hydroxide until $\mathrm{pH}$ about 5.0 , the solid was collected by filtration and purified to give compound (2) and (3), table 1 and 2.

${ }^{13} \mathrm{C}-\mathrm{NMR}\left(\mathrm{CDCl}_{3}\right) \delta$ compound (2), 55.80, 158.20, 114.36, 130.25, $132.58,130.25,114.28,46.41,159.89,112.25,148.25,64.30,55.70$, $66.70,66.70,55.70,100.80,133.69,114.67,156.39,147.25$.

${ }^{13} \mathrm{C}-\mathrm{NMR}\left(\mathrm{CDCl}_{3}\right) \delta$ compound (3), 55.80, 158.30, 114.21, 130.50, 132.64, 130.58, 114.36, 46.37, 159.37, 112.31, 148.80, 64.39, 55.70, $66.70,66.70,55.70,101.52,127.10,137.90,159.90,153.90$.

Preparation of the 7-chlor-2-(4'-methoxybenzylamine)-4morpholinomethyl-1,8-naphthyridine (4) and 7-chlor-2-(4'methoxy-benzylamine)-6-nitro-4-morpholinomethyl-1,8naphthyridine (5)

A mixture of the appropriate hydroxyl-1,8-naphthyridine (2) or (3) $(10 \mathrm{mmole})$, and $\mathrm{POCl}_{3}(15 \mathrm{ml})$ was heated at $90{ }^{\circ} \mathrm{C}$ for $45 \mathrm{~min}$. After cooling, the solution obtained was treated with ice and $\mathrm{H}_{2} \mathrm{O}$ and alkalinized with concentrated $\mathrm{NH}_{4} \mathrm{OH}$. The solid obtained (compound 4 or 5) was washed with $\mathrm{H}_{2} \mathrm{O}$ and purified by crystallization, table 1 and 2 .

${ }^{13} \mathrm{C}$-NMR $\left(\mathrm{CDCl}_{3}\right) \delta$ compound (4), 55.80, 158.60, 130.25, 132.35, $130.25,114.31,46.60,159.68,112.34,148.35,64.30,55.70,66.70$, $66.70,55.70,116.30,137.67,120.35,148.98,156.24$.

${ }^{13} \mathrm{C}$-NMR $\left(\mathrm{CDCl}_{3}\right) \delta$ compound $(5), 55.84,156.25,114.87,130.28$, 132.30, 130.54, 114.25, 46.40, 159.36, 112.70, 148.80, 64.32, 55.70, $66.70,66.70,55.70,117.21,131.30,144.78,145.35,162.71$.

Preparation of 2-(4'-methoxybenzylamine)-7-morpholino-4morpholinomethyl-1,8-naphthyridine (6) and 2-(4'-methoxybenzylamine)-6-nitro-7-morpholino-4-morpholinomethyl-1,8naphthyridine (7)

A mixture of 7-chloro-2-(4'-methoxybenzylamine)-4-morpholinomethyl-1,8-naphthyridine (4) or 7-chloro-2-(4'-methoxybenzylamine)-6-nitro-4-morpholinomethyl-1,8-naphthyridine (5) (1 mmole) and morpholine ( 2 mmole) was heated in a sealed tube at $140{ }^{\circ} \mathrm{C}$ for $12 \mathrm{~h}$, the resulting crude residue was treated with water and the solid was collected by filtration and purified by crystallization to obtain morpholino derivatives (6) or (7), table 1 and 2.

${ }^{13} \mathrm{C}-\mathrm{NMR}\left(\mathrm{CDCl}_{3}\right) \delta$ compound (6), 55.87, 158.35, 114.10, 130.25, 132.25, 130.25, 114.25, 46.38, 159.58, 112.70, 148.25, 64.35, 55.70, $66.70,66.70,55.70,106.90,136.25,109.95,154.10,155.10,48.70$, $66.30,66.30,48.70$.

${ }^{13} \mathrm{C}$-NMR $\left(\mathrm{CDCl}_{3}\right) \delta$ compound $(7), 55.80,158.31,114.10,130.25$, $132.25,130.25,114.10,46.25,159.00,112.70,148.80,64.36,55.70$, $66.70,66.70,55.70,107.36,130.25,129.68,152.36,161.25,47.70$, $66.30,66.30,47.70$.

Preparation of 2-(4'-methoxybenzylamine)-7-(piperidin-1-yl)4-morpholinomethyl-1,8-naphthyridine (8) and 2-(4'methoxybenzylamine)-6-nitro-7-(piperidin-1-yl)-4morpholinomethyl-1,8-naphthyridine (9)

A mixture of 7-chloro-2-(4'-methoxybenzylamine)-4-morpholinomethyl-1,8-naphthyridine (4) or 7-chloro-2-(4'-methoxybenzylamine)-6-nitro-4-morpholinomethyl-1,8-naphthy-ridine (5) $(1 \mathrm{mmole})$ and piperidine ( $2 \mathrm{mmole})$ was heated in a sealed tube at $140{ }^{\circ} \mathrm{C}$ for $12 \mathrm{~h}$, the resulting crude residue was treated with water and the solid was collected by filtration and purified by crystallization to obtain piperidine derivatives (8) or (9), table 1 and 2.
${ }^{13} \mathrm{C}-\mathrm{NMR}\left(\mathrm{CDCl}_{3}\right) \delta$ compound (8), 55.87, 158.62, 114.36, 130.25, $132.58,130.25,114.87,46.25,159.36,112.70,148.80,64.30,55.70$, $66.70,66.70,55.70,106.91,136.25,109.95,154.25,155.12,47.20$, $25.50,24.50,25.51,47.20$.

${ }^{13} \mathrm{C}$-NMR $\left(\mathrm{CDCl}_{3}\right) \delta$ compound (9), 55.84, 158.61, 114.25, 130.25, $132.65,130.54,114.10,46.41,159.58,112.70,148.84,64.30,55.70$, $66.70,66.70,55.70,107.87,130.30,129.01,152.80,161.35,51.70$, $25.50,24.50,25.50,51.70$.

\section{Preparation of 6-amino derivatives (10) and (11)}

A solution of 1.1 mmoles of 6-nitro derivatives (7) or (9) in glacial acetic acid was hydrogenated in the presence of $30 \mathrm{mg}$ of $10 \%$ palladium on charcoal at room temperature and at atmospheric pressure for $3 \mathrm{~h}$.

The catalyst was filtered and the solvent evaporated to dryness in vacuo to give compound (10) or (11), which was purified by crystallization, table 1 and 2 .

${ }^{13} \mathrm{C}$-NMR $\left(\mathrm{CDCl}_{3}\right) \delta$ compound (10), 55.80, 158.24, 114.21, 130.25, $132.25,130.36,114.25,46.38,159.98,112.70,148.84,64.36,55.70$, $66.70,66.70,55.70,107.84,123.80,132.58,152.68,144.32,48.70$, $66.30,66.30,48.70$.

${ }^{13} \mathrm{C}$-NMR $\left(\mathrm{CDCl}_{3}\right) \delta$ compound (11), 55.81, 158.36, 114.10, 130.25, 132.36, 130.25, 114.10, 46.98, 159.68, 112.30, 148.91, 64.30, 55.70, $66.70,66.70,55.70,107.25,123.80,132.25,152.20,52.70,25.50$, $24.50,25.50,52.70$.

\section{Biological evaluation}

\section{Minimum inhibitory concentration (MIC) determination}

The 7H12 broth medium which contained [14]C-labeled substrate (palmitic acid) as a single source of carbon, was used in these studies. Growth of Mycobacterium tuberculosis H37Rv led to consumption of the substrate and release of $[14] \mathrm{CO}_{2}$ into the atmosphere above the medium in the sealed vial, and the BACTEC 460 TB (Johnston Laboratories, Towson, Md) was used to detect the amounts of [14] $\mathrm{CO}_{2}$ and recorded it as growth index (GI) [17]. Appropriate solutions of the studied compounds were added in a volume of $0.1 \mathrm{ml}$ to vials containing $7 \mathrm{H} 12$ broth medium, to achieve the desired final concentrations. One 7H12 broth medium, inoculated with $M$. tuberculosis H37Rv that had reached a sufficient growth detected radiometrically (GI $=400$ 500 ) was used as an inoculum. $0.1 \mathrm{ml}$ of this broth pretest vial was added undiluted and two drug-free controls were used; one vial was inoculated to match the drug-containing test vials, and the seconds was inoculated with a 1:100 dilution of the inoculum to represent $1 \%$ of the bacterial population of the other vials. The vials were incubated at $37{ }^{\circ} \mathrm{C}$ and the GI readings were recorded daily. The MIC was determined radiometrically in $7 \mathrm{H} 12$ broth medium. It was defined as the lowest concentration of the drug which produces, for $3 \mathrm{~d}$, a daily GI increase and final GI reading lower than those in the 1:100 controls, and corresponds to the daily concentration that resulted in $>99 \%$ inhibition of the bacterial population growth.

\section{Statistical analysis}

All measurements were made in triplicate and each experiment was performed on two separate occasions; data are expressed as the mean \pm standard error of the mean (SEM). Differences were judged to be statistically significant when $p$ value equal to or below 0.05 . Statistical analysis was conducted using SPSS 11.5 statistical software.

\section{RESULTS}

The synthetic pathways employed to prepare the new targeted derivatives are depicted in Schemes 1 and 2 .

The 7-acetylamino-2-chloro-4-morpholinomethyl-1,8-naphthyridine (X) [18], was treated with 4-methoxy benzylamine to obtain 7amino-2-(4'-methoxybenzylamine)-4-morpholinomethyl-1,8naphthyridine (1), (scheme 1$)$. 


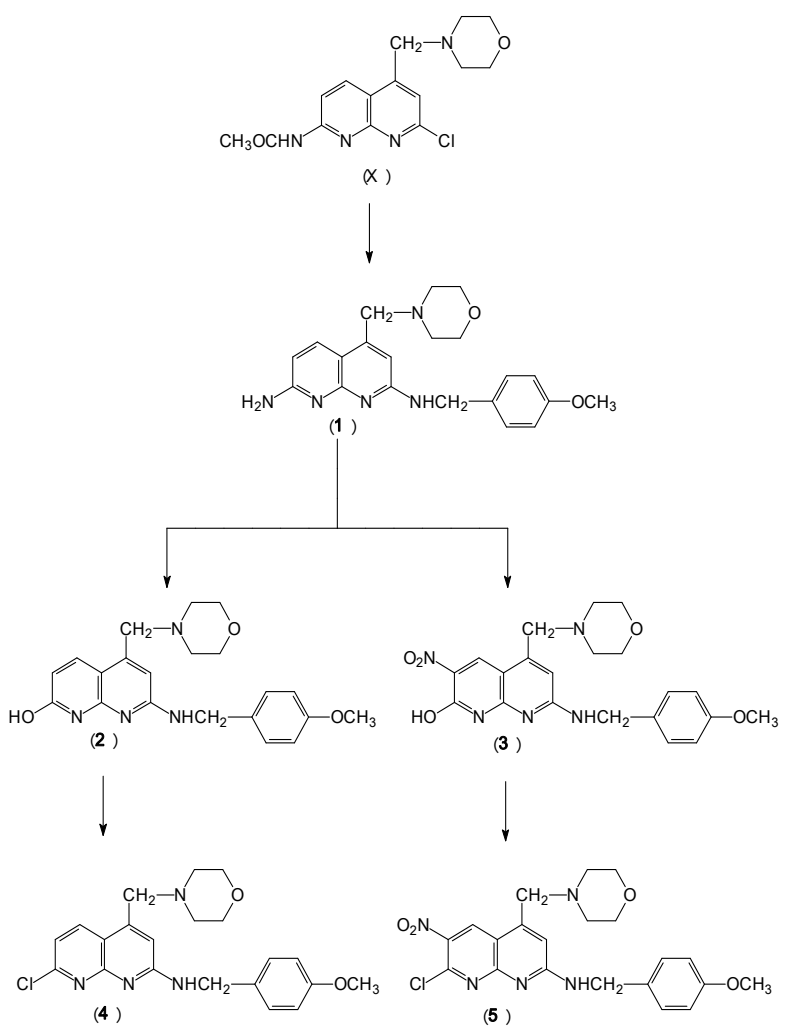

Scheme 1: Synthetic pathways of intermediate 1and target compounds 2-5

Diazotization of the 7-amino derivative (1) was effected with nitrous acid at-5 ${ }^{\circ} \mathrm{C}$ to get the 7-hydroxy-2-(4'-methoxybenzylamine)-4morpholinomethyl-1,8-naphthyridine (2), and 7-hydroxy-2-(4'methoxybenzylamine)-4-morpholinomethyl-6-nitro-1,8-naphthyrridine (3), (scheme 1). Introduction of lipophilic groups in position 7, of 1,8naphthyridine nucleus such as morpholine, and piperidine was obtained by the treatment of 7-hydroxy derivative (2) and (3) with phosphoryl chloride to obtain the relative 7-chloro-2-(4'-methoxybenzylamine)-4morpholinomethyl-1,8-naphthyridine (4), and 7-chloro-2-(4'-methoxybenzylamine)-4-morpholino-methyl-6-nitro-1,8-naphthyridine (5), (scheme 1). Which were subsequently treated with morpholine to obtain 7-morpholino-2-(4'-methoxybenzylamine)-4-morpholinomethyl-1,8naphthyridine (6) and 7-morpholino-2-(4'-methoxybenzylamine)-4morpholinomethyl-6-nitro-1,8-naphthyridine (7), (scheme 1).

The treatment of 7-chloro derivatives (4) and (5) with piperidine, lead to 2-(4'-methoxybenzylamine)-4-morpholinomethyl-7-piperidinyl1,8-naphthyridine (8), and 2-(4'-methoxybenzylamine)-4-morpholinomethyl-6-nitro-7-piperidinyl-1,8-naphthyridine (9).

The 6-nitro derivatives (7) and (9) were reduced with palladium to 6amino-2-(4'-methoxybenzylamine)-4-morpholinomethyl-7-morpholino1,8-naphthyridine (10) and 6-amino-2-(4'-methoxy-benzylamine)-4morpholinomethyl-7-piperidinyl-1,8-naphthyridine (11), (scheme 2).

All the newly synthesized compounds were evaluated for their in vitro anti-tuberculosis activity against Mycobacterium tuberculosis by use of the BACTEC analysis as part of a TAACF TB screening program.

The purpose of the screening program is to check the efficacy of the compound under test to inhibit the growth of M. tuberculosis H37Rv, according to the method described by Collins and franzblau [19]. Mycobacterium tuberculosis H37Rv, susceptible to all antitubercular drugs was preserved frozen before use.

Initial drug dilutions were prepared in dimethyl sulfoxide (DMSO) and stored in aliquots at $-70^{\circ} \mathrm{C}$. From these stock solutions, working solutions were prepared in sterile distilled $\mathrm{H}_{2} \mathrm{O}$ and incorporated into 7H12 broth medium (Johnston Laboratories, Towson, Md).<smiles></smiles>

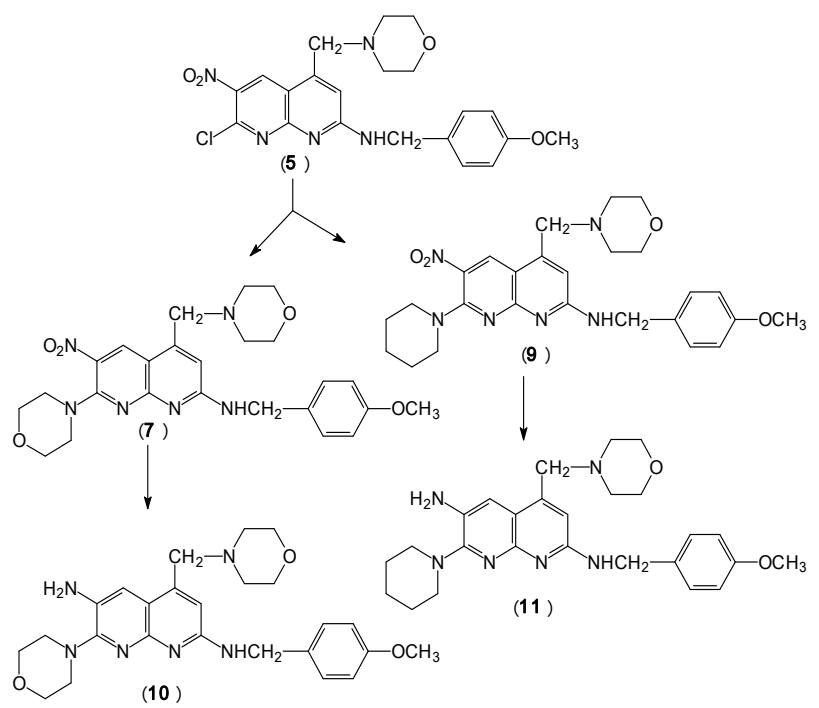

Scheme 2: Synthetic pathways of intermediates 6,7,9 and target compounds $8,10,11$

Primary screening was conducted at a single concentration, $7 \mu \mathrm{g} / \mathrm{ml}$ against Mycobacterium tuberculosis H37Rv in BACTEC 12B medium using a broth microdilution assay. Rifampicin was used as a reference drug due to his low MIC $(0.25 \mu \mathrm{g} / \mathrm{ml})$. Experiments were performed in triplicate, and results were consistent between the three samples.

Compounds effecting $<90 \%$ inhibition in the primary screening were not generally evaluated further. The active compounds were retested by serial dilution beginning at $6.25 \mu \mathrm{g} / \mathrm{ml}$ against Mycobacterium tuberculosis $\mathrm{H} 37 \mathrm{Rv}$ to determine the actual minimum inhibitory concentration (MIC) in BABTEC 460.

As shown in table 3 , the synthesized compounds were assessed for their activities against Mycobacterium tuberculosis $\mathrm{H} 37 \mathrm{Rv}$ in vitro. All the compounds (1-11) were active against the Mycobacterium tuberculosis with MIC in the range of 0.25-1.5 $\mu \mathrm{g} / \mathrm{ml}$, and the activity of most compounds showed MIC values lower than $0.6 \mu \mathrm{g} / \mathrm{ml}$.

Compound 10 emerged as the most potent analogue with good antimycobacterial activity $(\mathrm{MIC}=0.25 \mu \mathrm{g} / \mathrm{ml}$ ). Compound 11 also possessed reasonable activity with a MIC value of 0.31 $\mu \mathrm{g} / \mathrm{ml}$.

Besides, derivatives 8, 9, 7, and 6 displayed moderate activity $(\mathrm{MIC}=$ 038-0.50 $\mu \mathrm{g} / \mathrm{ml}$ ). On the other hand, compounds 5, 4, 3, 2, and 1 exhibited modest antimycobacterial activity with MIC values ranging from 0.58 to $1.5 \mu \mathrm{g} / \mathrm{ml}$. On the basis of the biological results, the most effective substituent in positions 7 seems to be the morpholine and piperidinyl group. Catalytic reduction of the nitro group in position 6 to the relative amino groups exhibited the highest activities in the series. 
Table 3: MIC ( $\mu \mathrm{g})$ values against Mycobacterium tuberculosis H37Rv in vitro

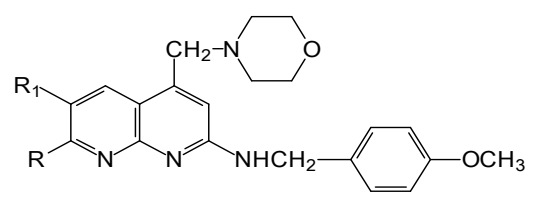

\begin{tabular}{llll}
\hline Comp. & $\mathbf{R}$ & $\mathbf{R}^{\mathbf{1}}$ & $\mathbf{M I C} \boldsymbol{\mu g} / \mathbf{m l}$ \\
\hline 1 & $\mathrm{NH}_{2}$ & $\mathrm{H}$ & $1.50 \pm 0.09$ \\
2 & $\mathrm{OH}$ & $\mathrm{H}$ & $0.90 \pm 0.06$ \\
3 & $\mathrm{OH}$ & $\mathrm{NO}_{2}$ & $0.70 \pm 0.03$ \\
4 & $\mathrm{Cl}$ & $\mathrm{H}$ & $0.73 \pm 0.05$ \\
5 & $\mathrm{Cl}$ & $\mathrm{NO}_{2}$ & $0.58 \pm 0.02$ \\
6 & $\mathrm{Pip}$ & $\mathrm{NO}_{2}$ & $0.50 \pm 0.03$ \\
7 & $\mathrm{Pip}$ & $\mathrm{H}$ & $0.45 \pm 0.04$ \\
8 & Morph & $\mathrm{NO}_{2}$ & $0.38 \pm 0.02$ \\
9 & Morph & $\mathrm{NH}_{2}$ & $0.42 \pm 0.06$ \\
10 & Morph & $\mathrm{NH}_{2}$ & $0.25 \pm 0.04$ \\
11 & Pip & & $0.31 \pm 0.03$ \\
Rifampicin & & $0.25 \pm 0.06$ \\
\hline
\end{tabular}

All measurements were made in triplicate and each experiment was performed on two separate occasions, Values are mean \pm SEM ( $=3$ ), Morph: morpholine pip: piperidine.

\section{DISCUSSION}

The growing number of multidrug-resistant (MDR-TB) cases resulted in the need for the continuous discovery and development of new anti-tuberculosis entities. In this context, this paper focuses on the synthesis of potent compounds with minimum inhibitory concentration (MIC) in the micromolar range i.e., a very high activity when compared with our previously synthesized compounds which show an average MIC value of $6.25 \mu \mathrm{g} / \mathrm{ml}$.

Naphthyridines constitute an important class of antibacterial agents, and upon the basis of this observation, we have reported the synthesis of a set of new 1,8-naphthyridines that were active against the M. tuberculosis H37Rv strain [20]. Among these compounds 2, 7di-(piperidin-1-yl)-4-phenyl-1,8-naphthyridine appeared to have a good activity with MIC of $6.25 \mu \mathrm{g} / \mathrm{ml}$ [15]. Thus, as an extension of our research, we designed and synthesized a series of novel 1,8naphthyridine derivatives which are of great potential interest that would be expected to provide highly desirable intermediates for the synthesis of new drug candidates.

The discovery of various anti-tuberculosis drugs is based on the growth susceptibility to drug treatment. We have used the sophisticated BACTEC liquid broth growing technique to monitor the growth inhibition of $M$. tuberculosis $\mathrm{H} 37 \mathrm{Rv}$ by eleven of our candidate drugs and the acquisition of MIC values against M. tuberculosis. Results of the biological assay clearly indicate that the compounds containing 6amino-morpholinyl substituents are more potent than their corresponding 6-amino-piperidinyl series. The most prominent compound 6-amino-2-(4'-methoxy benzylamine)-4-morpholinomethyl7-morpholino-1,8-naphthyridine (10), exhibited activity comparable to that of the reference standard, rifampicin (MIC $0.25 \mu \mathrm{g} / \mathrm{ml}$ ). However, we can note that the activities of compounds (6-11) having heterocyclic groups in position 7 such as morpholine and piperidine were quite different from those having an amine, hydroxy or chloro in position 7. Intriguingly, inhibitory concentrations of newly synthesized compounds were approximately four or more orders of magnitude lower than those determined for the previously synthesized 1,8-naphthyridine analogues. According to the literature [21] candidates for new drugs must have a MIC values lower than 6.25 $\mu \mathrm{g} / \mathrm{ml}$, as is indeed the case for all tested compounds.

This study could lead to greater molecular diversity in new 1,8naphthyridines analogues, which are of great potential interest for the synthesis of new drug candidates. To the best of our knowledge, compounds (1-11) are herein reported for the first time. However, the ascertaining the therapeutic potential of this class of compounds as anti-mycobacterial agents still require an evaluation of most effective analogue 10 against drug-resistant strains of $M$. tuberculosis.

\section{CONCLUSION}

Several 4-morpholinomethyl-1.8-naphthyridine derivatives, variously modified were synthesized, and their antitubercular activities against Mycobacterium tuberculosis strain $\mathrm{H} 37 \mathrm{Rv}$ were in vitro determined.

The obtained results indicated that the new 1,8-naphthyridine analogue (10) with a 6-amino-2-(4'-methoxybenzylamine-4morpholinomethyl-7-morpholino-substituent was the most potent analogue of this series with MIC of $0.25 \mu \mathrm{g} / \mathrm{ml}$ and offers a promising new lead for further development.

\section{ACKNOWLEDGMENT}

This work was supported by the Deanship of Scientific Research, Jerash University.

\section{CONFLICT OF INTERESTS}

The authors declare that they have no conflict of interest.

\section{REFERENCES}

1. The World Health Organization (WHO) Global tuberculosis report; 2015. Available from: www.who.int/tb/data. [Last accessed on 10 May 2016].

2. Frieden TR, Sterling TR, Munsiff SS, Watt CJ, Dye C. Tuberculosis. Lancet 2003;362:887-99.

3. Ginsburg AS, Grosset JH, Bishai WR. Fluoroquinolones, tuberculosis, and resistance. Lancet Infect Dis 2003;3:432-42.

4. Zignol M, Hosseini MS, Wright A, Weezenbeek CL, Nunn P, Watt CJ, et al. Global incidence of multidrug-resistant tuberculosis. J Infect Dis 2006;194:479-85.

5. Ozadali K, Tan OU, Yogeeswari P, Dharmarajan S, Balkan A. Synthesis and antimycobacterial activities of some new thiazolyl hydrazone derivatives. Bioorg Med Chem Lett 2014;24:1695-7.

6. Kurniawati F, Sulaiman SAS, Gillani SW. Study on drugresistant tuberculosis and tuberculosis treatment on patients with drug-resistant tuberculosis in chest clinic outpatient department. Int J Pharm Pharm Sci 2012;4:733-7.

7. Siddiqui S, Baig MMA, Jaffer S, Ansari SFR. Study on prevalence of adverse drug reactions in patients suffering from tuberculosis in a tertiary care hospital. Int J Pharm Pharm Sci 2016;8:375-7.

8. Global alliance for TB drug development; 2008. Available from: http://www.tballiance.org/home/home.php. [Last accessed on 10 May 2016] 
9. Dorman SE, Chaisson RE. From magic bullets back to the magic mountain: the rise of extensively drug-resistant tuberculosis. Nat Med 2007;13:295-8.

10. Hussein MA, Aboul-fadi T, Hussein A. Synthesis and antitubercular activity of some mannich bases derived from isatin isonicotinic acid hydrazine. Bull Pharm Sci Assiut Univ 2005;28:131-6.

11. Sriram D, Aubry A, Yogeeswari P, Fisher LM. Gatifloxacin derivatives: synthesis, antimycobacterial activities, and inhibition of Mycobacterium tuberculosis DNA gyrase. Bioorg Med Chem Lett 2006;16:2982-5.

12. Mukesh M, Manju P, Sabitha M. Structural model of the alpha phosphoglucomutase: a promising target for the treatment of Mycobacterium tuberculosis. Int J Pharm Pharm Sci 2013;5:107-14.

13. Perumal P, Pandey VP, Parasuraman P. Docking studies on antimicrobial peptides related to apidaecin-IA and human histatin against glutamine synthase and RNA polymerase in Mycobacterium tuberculosis. Asian J Pharm Clin Res 2014; 7:195-201.

14. Migliori GB, Ortmann J, Giradi E, Besozzi G, Lange C, Cirillo DM, et al. Extensively drug-resistant tuberculosis, Italy, and Germany. Emerging Infect Dis 2007;13:780-2.

15. Badawneh M, Bellini L, Cavallini T, Aljamal JA, Manera C, Saccomanni G, et al. Synthesis of 3-or 4-phenyl-1,8napththyridine derivatives and evaluation of antimycobacterial and antibacterial activity. Farmaco 2003;58:859-66.
16. Badawneh M, Aljamal JA. Synthesis of 4-morpholinomethyl-1,8naphthyridine derivatives with antimycobacterial activity. Alex J Pharm Sci 2003;17:105-9.

17. Middlebrook G, Reggiardo Z, Tigertt WD. Automatable radiometric detection of growth of Mycobacterium tuberculosis in selective media. Am Rev Respir Dis 1977;115:1067-9.

18. Aljamal JA, Badawneh M. Characterization of the biochemical effects of new 1,8-naphthyridine derivatives, $\beta$-receptor antagonists, in ventricular myocytes. Arch Pharm Pharm Med Chem 2003;336:285-92.

19. Collins LA, Franzblau SG. Microplate alamar blue assay versus BACTEC 460 system for high throughput screening of compounds against Mycobacterium tuberculosis and Mycobacterium Avium. Antimicrob Agents Chemother 1997;41:1004-9.

20. Badawneh M, Manera C, Mori C, Saccomanni G, Ferrarini PL. Synthesis of variously substituted 1,8-naphthyridine derivatives and evaluation of their antimycobacterial activity. Framaco 2002;57:631-9.

21. Orme I, Secrist J, Anathan S, Kwong C, Maddry J, Reynolds R, et al. Search for new drugs for the treatment of tuberculosis. Antimicrob Agents Chemother 2001;45:1943-6.

\section{How to cite this article}

- Muwaffag Badawneh, Jalal Aljamal. Synthesis and antitubercular activity of piperidine and morpholine 1, 8 naphthyridine analogues. Int J Pharm Pharm Sci 2016; 8(12):252-257. 